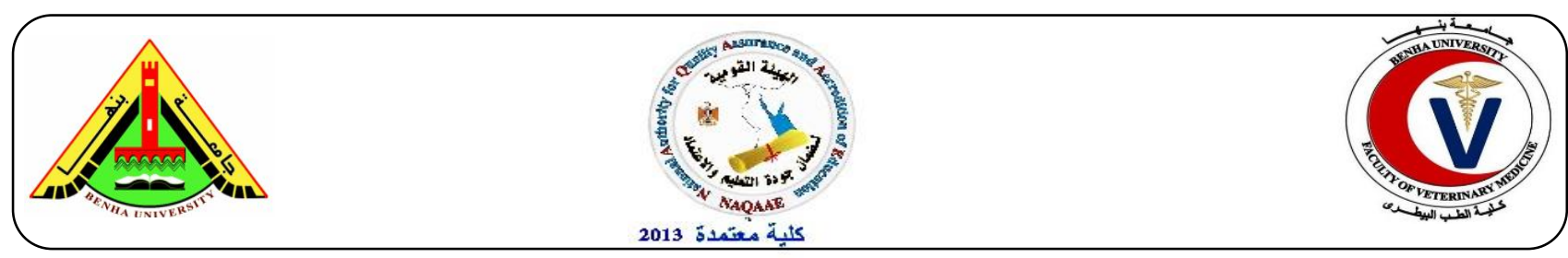

\title{
In-vitro studies on antiviral effects of Galaxaura elongata marine algae on white spot syndrome virus
}

\author{
Ahmed M. Abdel-Wahab \\ Central Laboratory for Aquaculture Research, Abbassa, Agriculture Research Center
}

\section{A B S T R A C T}

White spot syndrome virus is currently the most devastating viral pathogen threatening the shrimp farming industry worldwide. Studying efficiency of Galaxaura elongata as red marine algae on that shrimp virus was the aim of this work. Cells culture from lymphoid organ of Penaeid semesulacatus were established and when confluent cell monolayer was formed, the cell were infected with $0.1 \mathrm{ml}$ virus of titer 106.4 TCID50/ml mixed with $(5,10,20 \mu \mathrm{l})$ algal extract. Data cleared algal extract of G. elongata has antiviral effect to WSSV where it results in reduction of virus titer $1.3 \operatorname{logs}$ at concentration $5 \mu \mathrm{l} /$ well, $2.2 \operatorname{logs}$ at concentration $10 \mu \mathrm{l} /$ well and the highest reduction was at concentration $20 \mu \mathrm{l} /$ well which was $(2.5 \log 10 \mathrm{TCID} 50)$. Algal extract was reduced CPE of infected cells in the attachment assays by 55,70 and $75 \%$ consecutively and in the trypsin inhibition assay a significant activity was determined for $10 \mu \mathrm{l}$ extract concentration. So, it can be suggested that using of G. elongata as red algae has vitro effect against WSSV replication.

Keywords: White spot syndrome virus, Galaxaura elongata and shrimp.

(http://www.bvmj.bu.edu.eg)(BVMJ-34(1): 162-171, 2018)

\section{INTRODUCTION}

Penaeid shrimp culture has taken up predominant position in aquaculture industry attaining globally the sixth position in terms of value among all taxonomic groups of animals cultivated. This is primarily due to the rapid growth of high density culture and its expansion in all shrimp growing Nations (Mayer and Hamann, 2005).

Tragically, concomitant with this development has been the rapid spread of diseases over the shrimp farms worldwide causing severe financial losses. The most important disease of cultured penaeid shrimp in term of economic impact in Asia, Indo pacific and Americas have infectious agents as their cause. Among the infectious diseases of cultured shrimp, certain viruses caused diseases stand out as the most significance. Viral agents were once limited in distribution to either the Western or Eastern Hemisphere. The international movement of live shrimp for aquaculture and dead for reprocessing and commerce has led to the transfer and establishment of certain pathogens from one hemisphere to another, viral diseases are the major problem in the shrimp aquaculture industry worldwide (Khuong et al., 2017). 
About 20 types of viruses have been reported in penaeid shrimp, among which the white spot syndrome virus (WSSV) has been responsible for the highest economic loss to the industry. WSSV is currently the most devastating viral pathogen threatening the shrimp farming industry worldwide characterized by high and rapid mortality accompanied by gross signs in moribund shrimp of white, initially circular, inclusions or spots in the cuticle, sometimes accompanied by overall red body coloration. With disease progression is characterized by cessation of shrimp feeding followed within a few days by the appearance of moribund shrimp swimming near the surface at the edge of rearing ponds (Eissa et al., 2009).

In Egypt, several studies were done on WSSV of shrimp as isolation and identification of white spot syndrome virus from Egyptian marine shrimp (Salama et al., 2008), diagnosis of white spot syndrome virus among marine shrimp (Eissa et al., 2009) and improving isolation of white spot syndrome virus on mammalian cell lines (Salama et al., 2009).

Plants have a long evolution of resistance against viral agents and lead to alternative directions in drug development. Therefore, extracts of plants and phytochemicals are getting more importance as potential sources for viral inhibitors during the recent decade. Extensive studies have shown that medicinal plants of several parts of the world contain compounds active against viruses that cause human diseases. Thus plants used also in Nepalese traditional medicine were analyzed (Cox et al., 2010).

The literature survey found that the marine red algae are rich sources of phenolic compounds especially bromophenols. Phenolic substances were reported to possess a wide range of biological effects, including antioxidant, antimicrobial, anti-inflammatory and vasodilator actions (Li et al., 2010).

Galaxaura elongata as red marine algae is considered as a source of bioactive compounds as it is able to produce a great variety of secondary metabolites characterized by a broad spectrum of biological activities. Compounds with antioxidant, antiviral, antifungal and antimicrobial activities have been detected in red algae (Cox et al., 2010).

The aim of this work based on studying efficiency of $G$. elongata on the WSSV infection to shrimp tissue culture.

\section{MATERIALS AND METHODS}

\section{Shrimp and tissues:}

Apparent healthy Penaeid semesulacatus shrimp, about $15-20 \mathrm{~cm}$ in length and weighted 40-60 gm, were collected from Suez canal governorate and maintained in aerated fresh sea water until used. Lymphoid organ was used for cell culture initiation (Photo 1).

\section{Establish of primary cell culture}

Shrimp were anaesthetized by adding $2 \mathrm{ml}$ of the clove oil solution (9 parts ethanol with 1 part clove oil) in 5L of water containing shrimp. Surface disinfection was carried out by $70 \%(\mathrm{v} / \mathrm{v})$ ethanol. Tissues were removed aseptically and washed four times in phosphate buffer saline (PBS) containing antibiotics $(500 \mathrm{IU} / \mathrm{ml}$ penicillin, $500 \mu \mathrm{g} / \mathrm{ml}$ streptomycin and $2.5 \mu \mathrm{g} / \mathrm{ml}$ amphotericin B). Lymphoid organ was minced into small pieces and washed four times in Modified Eagle's minimum essential medium (EMEM) with Earl's balanced salt solution and L. glutamine medium(Sigma, cat. No. M. 4642, St. Louis, USA) supplemented with $2 \%$ glucose, vitamins 
(IX), tryptose phosphate broth (2.95gm) $20 \% \mathrm{FBS}$, containing antibiotics $\left(500 \mathrm{IU} \mathrm{ml}^{-1}\right.$ penicillin, $500 \mu \mathrm{g} \mathrm{ml}^{-1}$ streptomycin and 2.5 $\mu \mathrm{g} \mathrm{ml}^{-1}$ Fungizone). The minced tissue fragments were inoculated into $25 \mathrm{~cm}^{2}$ cell culture flasks containing $10 \mathrm{ml}$ of complete growth medium and the flasks $\left(50 \mathrm{~cm}^{2}\right.$ Falcon Div. Becton Co. USA) were incubated at $28{ }^{\circ} \mathrm{C}$ and outgrowth of the attached explants was observed daily (Shimizu et al., 2001).

When $80 \%$ confluence was achieved; the medium in tissue culture flasks were carefully removed with pipette and the cell monolayer was subcultured at 1:3 ratios with complete medium.

\section{Preparation of the algal sample}

G. elongata (Photo. 2) was collected from Abo Quire beach of Alexandria and put in polyethylene bags after cleaning thoroughly with fresh water to remove adhering debris or associated biota. The alga was cleaned using a brush for the removal of the epiphytes with distilled water then dried in shade at $70{ }^{\circ} \mathrm{C}$ in vacuum oven for 2 days. After drying the sample has been grounded mechanically by electrical mixer to powder form and passed through $0.2 \mathrm{~mm}$ sieve (Tayloretal.,1996).

\section{Algal extraction}

Twenty five gm of $G$. elongata were soaked in $250 \mathrm{ml}$ of diethyl ether for $24 \mathrm{hr}$ then filtrated and concentrated under reduce pressure by using rotary evaporator (Photo. 3) (Tayloretal.,1996).

\section{Detection of cytotoxicity of algal extract to} culture cells

Cells were grown in tissue culture plates of 96 well (Greiner Bio- One) until $80 \%$ confluence shrimp cell cultures was achieved. Then growth media was removed and duplicate wells was received maintenance media mixed with different doses of crude algal extract $(5,10,20$ and $50 \mu \mathrm{l}$ per well). Cytotoxic effect of different doses of crude algal was determined based on microscopic examination of culture cells for estimation of cytopathic effect (CPE) (Cox et al., 2010).

Antiviral activity of $G$. elongata extract against WSSV

The antiviral activity of the $G$. elongata extract was determined based on CPE and virus titration according to (Harden et al., 2009). The cell cultures at $48 \mathrm{~h}$ seeded with confluent monolayer were infected with $0.1 \mathrm{ml}$ stock WSSV $10^{6.4} \mathrm{TCID}_{50} / \mathrm{ml}$ isolated from infected shrimp by Salama et al., (2009) mixed with $(5,10,20 \mu \mathrm{l})$ algal extract at the time $50 \mu \mathrm{l}$ per well algal extract was excluded. Duplicate wells were infected with $0.1 \mathrm{ml}$ virus alone and the other inoculated with only maintenance media. Cells were examined daily under inverted microscopic to detect the formed CPE.

The infected cells were fixed with acetone/methanol (50:50) at $4^{\circ} \mathrm{C}$ and stained with a $1 \%$ solution of crystal violet, and the number of the plaques counted. The percentage of inhibition of plaque formation was calculated as follows: [(mean number of plaques in control) - (mean number of plaques in test)] / (mean number of plaques in control) $\mathrm{x} 100$

\section{Attachment assay}

The ability of the viruses to attach to the host cell and replicate inside the cell in the presence of plant extract was tested using the method of Cos et al. (2006).

Cells appropriate for the growth of each virus were seeded in 96-well flat bottomed microtitre plates and incubated at $28{ }^{\circ} \mathrm{C}$ to attain an $80 \%$ confluent monolayer. Medium on the cells was removed and equal 
volumes of virus was added to cells and incubated at $2 \mathrm{~h}$ interval. Cells were washed with phosphate buffered saline (PBS) to remove the unattached viruses. Extract at noncytotoxic concentrations (5, 10 and $20 \mu \mathrm{l}$ ) was added onto cells and incubated again and observed daily for evidence of CPE. Negative controls comprised non-infected and untreated cells while positive controls consisted of infected and treated cells.

\section{Protease inhibition assay}

Proteaseinhibitoryactivitytestedbytry psininhibitionwasmonitoredwithBAPNA(c $\mathrm{x}$ - $N$-benzoyl-DL-arginine- $p$-nitroanilide). The proteases present in the sample of interest was digested the protein substrate and release dye labeled peptides. The absorbance of the dye-labeled peptide is measured at $570 \mathrm{~nm}$ for determination of protease activity (Swaminathan et al.,1992). The test was performed in duplicate and repeated for three times.

\section{Virus titration}

The virus was titrated based on tissue culture infected dose 50 according to Wanger and Hewllet (1999).

\section{RESULTS}

Culture of primary tissue culture

Cells obtained from the lymphoid organ fragments exhibited spherical like shape that observed in the outgrowth by 18 $\mathrm{h}$ post seeding. After 3-4 days, $70 \%$ confluent monolayer was achieved and these cells could be maintained for 5-7 days without changing medium. The cell viability was decreased after seven days in culture. It was established that one week in culture would be optimal for subculturing experiments.

Subculturing of the cell culture was done at $90 \%$ confluency in order to avoid the deterioration of the cells and increase the reseeding efficiency of the cells. The morphology of the cells showed rapid deterioration at high cell densities and floating of the dead cells was also noticed. The cells were subcultured at a ratio of $1: 3$ at 3-4 d interval (Photo. 4).

Detection of cytotoxicity of algal extract to culture cells

Four doses $(5,10,20$ and $50 \mu 1)$ of extract of tested algae were evaluated in cultured lymphoid organ. The obtained results showed no CPE in extracted of low doses (5, 10 and $20 \mu \mathrm{l}$ ) in cultured cells for 3 successive days while $50 \mu \mathrm{l}$ of the extract caused marked toxicity after $24 \mathrm{~h}$ in form of cell lyses and detachment from the micro titer plate ((Photo. 5).

Antiviral activity of $G$. elongata extract against WSSV

Antiviral activity of $G$. elongate was evaluated by inoculated the prepared cells with $0.1 \mathrm{ml}$ virus mixed with $(5,10,20 \mu \mathrm{l})$ algal extract. Within two days post infection, apparent cytopathic effect was observed in the inoculated primary shrimp tissue cultures. The infected cells initially exhibited shrinkage or became aggregated, and 5 days later, most of the infected cells rounded up and then detached from the culture dishes. In contrast, no obvious CPE was observed in the cell cultures which were inoculated with the same volume of PBS (Photo 6). The reduction in the virus titer showed in table (1). 
Table 1: Antiviral activity of G. elongata extract against WSSV

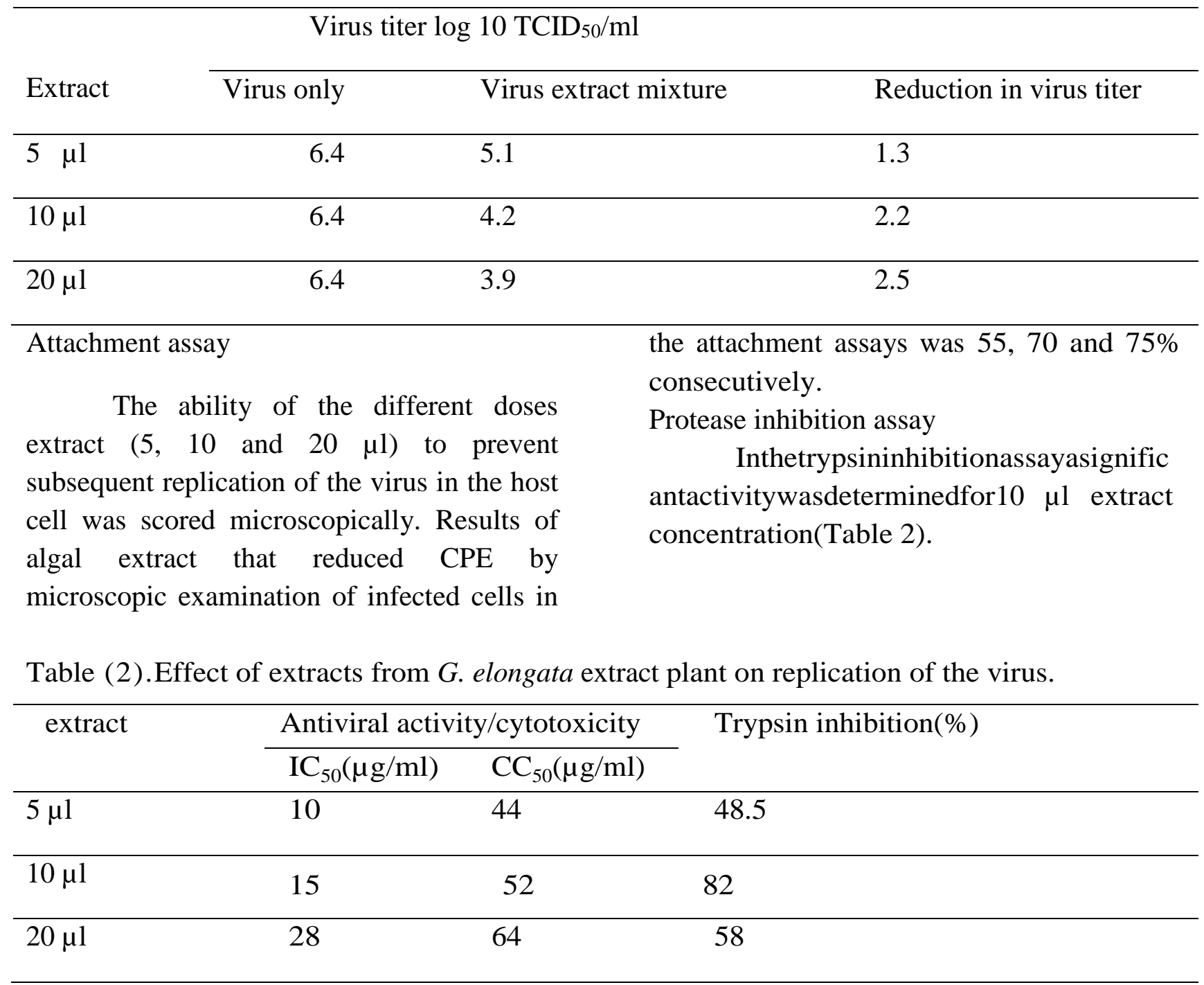

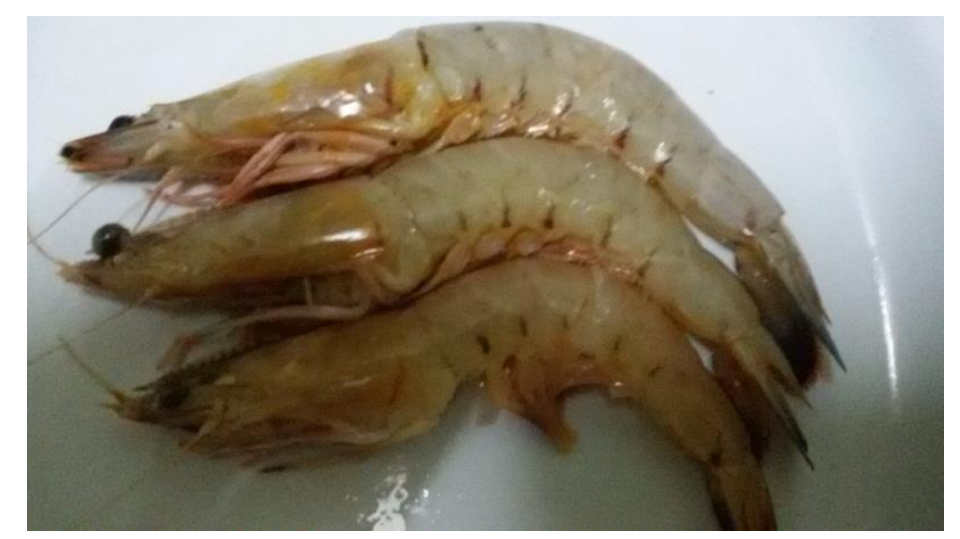

Photo. (1). Apparent healthy Penaeid used for establishment primary tissue culture 


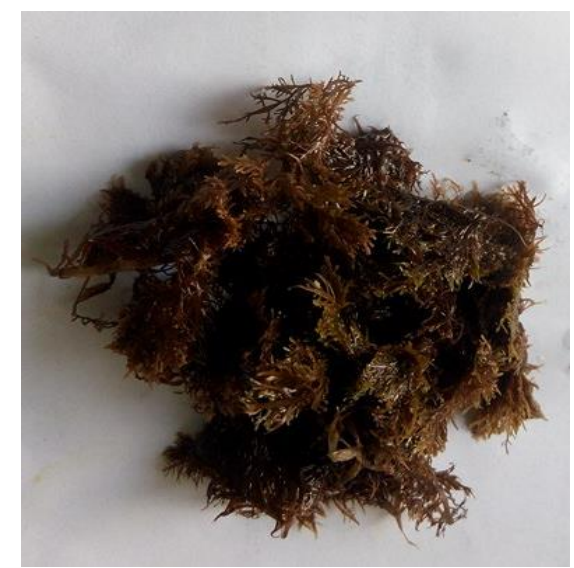

Photo. (2). Galaxaura elongata

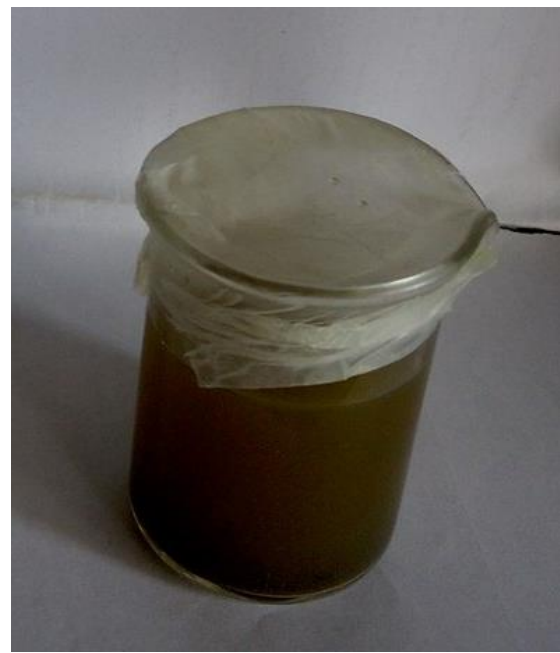

Photo. (3). Extract of Galaxaura elongata
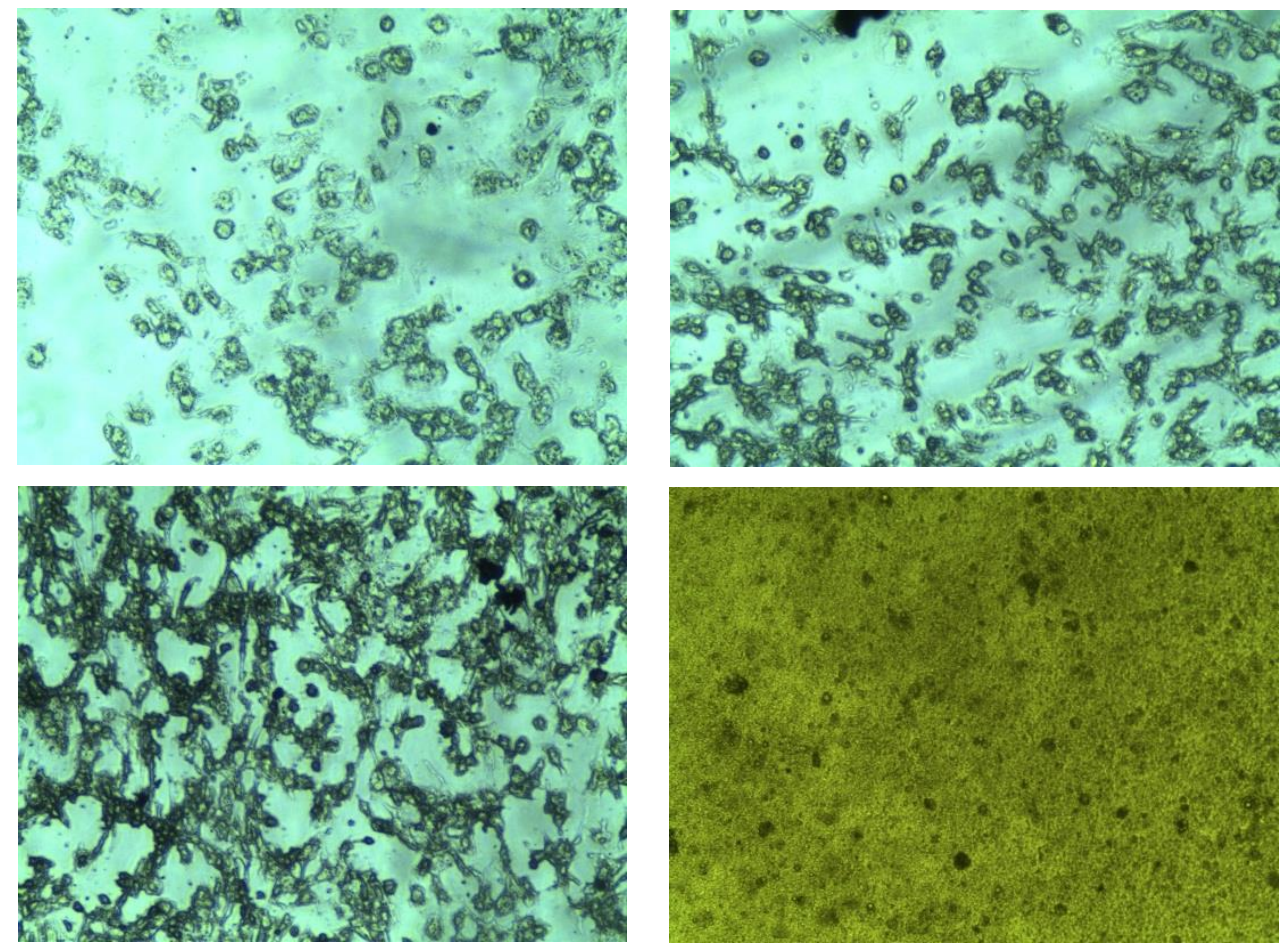

Photo. (4). Stages of formed primary tissue culture till formed confluent monolayer sheet (X 40) 

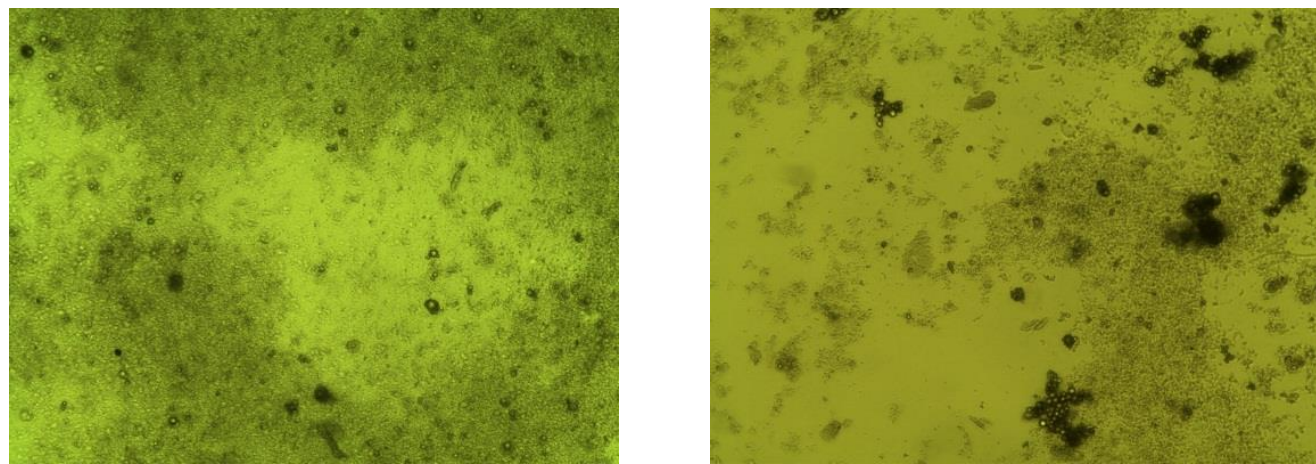

Photo.(5). Determination of cytotoxicity of algal extract to culture cells $\quad$ (X 40)
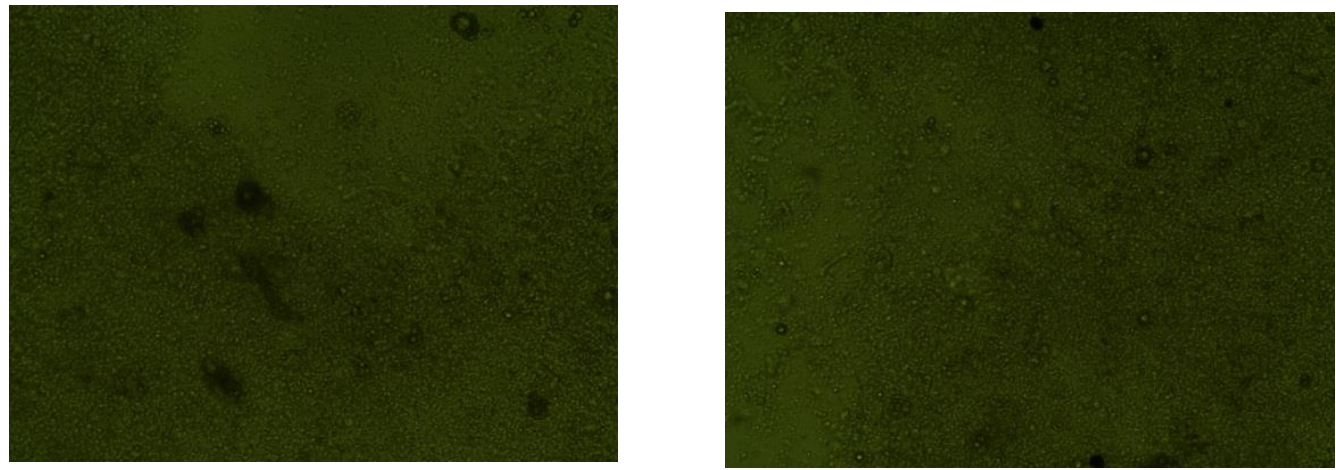

Photo. (6). Degrees of antiviral activity of algal extract (X 40)

\section{DISCUSSION}

There have been efforts in generating cell cultures from shrimp like the attempts made in other animal groups. However, the difference has been that all such efforts made in shrimp cell line development. Ever since the first reported cell culture from Penaeusmonodon(Wanger and Hewllet 1999), several researchers have been stepping in to the field and coming up with primary cell cultures from penaeid and non penaeid species.

In the present study, lymphoid organ was used for establishment of primary cell culture to detect antiviral effect of $G$. elongata against WSSV this cell kind was suggested by many authors as Shimizu et al., (2001) who recorded that primary cell cultures from lymphoid organ was developed from explants, which got attached to the culture vessel and cell migration started within a few hours. This cell culture was susceptible to WSSV and as cytopathic effect shrinkage, rounding, accumulation of retractile granules and detachment of infected cells was the common features in the event. Also, lymphoid organ has been a popular organ of choice for shrimp cell culture due to it is easy to locate and contains numerous mitotically active germ stem cells, which are promising for shrimp cell line establishment.

The obtained cell culture exhibited spherical like shape by $18 \mathrm{~h}$ post seeding. After 3-4 days, 70\% confluent monolayer was achieved. The difference in cell viability may be attributed to the weak binding of cells to the substrate after day 1 and a longer incubation period was needed to allow cells to attach firmly to the coated substrate.

Wanger and Hewllet (1999) recorded the need of tissue culture for subculture Because primary cultured cells have limited proliferative capacities invitro, attempts have been focused on the establishment of 
conditions for sub-cultivation. In present study the cell viability was decreased after seven days in culture and so, it would be optimal for subculturing which was done at $90 \%$ confluence.

Viral diseases are a major problem in the shrimp aquaculture industry worldwide and there serious viral outbreaks often cause catastrophic losses in shrimp farming around the globe. WSSV are the most important DNA virus infecting penaeid shrimp. Thus, identifying novel antiviral drugs is of critical importance and natural products are an excellent source for such discoveries. Antiviral compounds presently have a narrow spectrum of activity, limited therapeutic usefulness and variable toxicity. There is also an emerging problem of resistant viral strains. Herbal medicines and purified natural products provide a rich resource for novel antiviral drug development (Corteel et al., 2012).

This study was undertaken to examine antiviral activity of $G$. elongata thus firstly it was examined toxicity of algal extract to the established culture cells which was evaluated using different doses of crude extract separately $(5,10,20$ and $50 \mu \mathrm{l})$ and the results showed marked toxicity after $24 \mathrm{~h}$ with $50 \mu \mathrm{l}$ of the extract in form of cell lyses and detachment from the micro titer plate thus it was used doses of $(5,10$ and $20 \mu \mathrm{l}) /$ well for evaluation the antiviral activity of $G$. elongata and $50 \mu 1$ per well algal extract was excluded.

Data presents in table (1) cleared that the algal extract of $G$. elongata has antiviral effect to WSSV where it results in reduction of virus titer $1.3 \operatorname{logs}$ at concentration 5 $\mu 1 /$ well, $2.2 \operatorname{logs}$ at concentration $10 \mu \mathrm{l} /$ well the highest reduction was with concentration $20 \mu \mathrm{l} /$ well which was $\left(2.5 \log 10 \mathrm{TCID}_{50}\right)$.

The antiviral activity of $G$. elongata algae may attribute to its content of marine algal polysaccharides which results in blockage of viral adsorption points in cell membrane of the host cell. This speculation comes in agreement with finding of Cos et al. (2006) who reported antiviral activity of red algae due to presence of sulpholipids and polysaccharides in the algal extract. It is interest to declare that polysaccharides from G. elongata has been isolated and studied for antiviral activity in vitro against number of human and avian viruses as considerable inhibition of viral replication (Mayer and Hamann 2005). Beside the results cited by ( $\mathrm{Li}$ et al., 2010) who recorded that presence of various sulphated polysaccharides groups extracted from sea weed and red algae have phenolic substances were reported to possess a wide range of biological effects, including antiviral, antimicrobial, anti-inflammatory and antioxidant actions. Furthermore, tannins and flavonoids are defined as naturally occurring seaweed polyphenolic compounds which have been found only in marine algae which identified as antiviral of natural source can interact with the viral life cycle, such as viral entry, replication, assembly, and release, as well as on the targeting of virus-host-specific interactions.

The fact that degree of inhibition (55, 70 and $75 \%$ ) was observed with G. elongate extracts suggests to the active components that present in the extracts responsible for the observed activity. These substances capable of inactivating the virus as well as preventing its replication in the host system that was accepted by Camargo et al., (2008).

Activity of $G$. elongate as antiviral is geared towards inactivation of the virus prior to inoculation. Where inactivation doesnot occur prior to inoculation, virus can still induce CPE, but the plant extract may enter the cells together with the virus and induce an intracellular antiviral effect. However, it is presumed that the predominant activity in this assay is 
extracellular.

Proteases are enzymes which catalyze the hydrolysis of peptide bonds forming primary structure of proteins. They are common to organisms; from microorganisms to plants and animals. Protease assays are widely used for the investigation of protease inhibitors and detection of protease activities. Monitoring various protease activities has become a routine task for many biological laboratories and there is some proteases have been identified as good drug development targets. Besides the metabolic genes, many genes that may be involved in the innate immune system of the crustaceans, such as antimicrobial peptides, pattern recognition receptors, proteases and protease inhibitors, signal transduction proteins, apoptosis-, antioxidant-, and RNA interference-related proteins. The mRNA expression levels of crustin2, a lectin, and a digestive cysteine protease decreased after WSSV infection. G. elongata recorded high level of protease inhibitor activity can be inhibited the virus replication as assayed by Taylor et al. (1996) and that may be the cause of minimized the virus activity in present study.

\section{CONCLUSION}

It can be concluded that using of $G$. elongata as red algae has in-vitro effect against WSSV replication and can be tested as biological control in shrimp rearing ponds against the same virus special it can be cultivated in the same water supply. Further trials would be required to evaluate the absorption, distribution, metabolism and excretion of the active compounds present in extract to determine their therapeutic potential.

\section{REFERENCES}

Camargo Filho, I., Cortez, D.A.G., UedaNakamura, T., Nakamura, C.V., Dias Filho, B.P., (2008). Antiviral activity and mode of action of a peptide isolated from Sorghum bicolor. Phytomedicine 15, 202-208.

Corteel

M,

Mungai,G.M.,Muthaura,C.N.,Muli,J.M. ,and Keter,L.K. (2012): Moult cycle of laboratory-raised Penaeus (litopenaeus) vannamei and P. monodon. Aquacult Int 20:13-18.

Cos,P.,Vlietinck,A.J.,VandenBerghe,D. andMaes,L.,(2006).Anti-

infectivepotentialofnaturalproducts:how todevelopastrongerinvitro 'proofofconcept'.J.Ethnopharmacol.106,290302.

Cox, S., Abu-Ghannam, N. and Gupta, S., (2010). Novel antiviral agents: a medicinal plant perspective. J. Appl. Microbiol. 95, 412-427.

Eissa, I.A.M., A.F.H. Badran, Aos. Diab, S.F.M. Saker and A.A. Ahmed (2009). Diagnosis of white spot syndrome virus (WSSV) among marine shrimp. SCVMJ, IVXCD: 85-100.

Harden E.A., Falshaw R., Carnachan S.M., Kern E.R., Prichard M.N. (2009). A review on the morphology, molecular characterization, morphogenesis and pathogenesis of white spot syndrome virus. J Fish Dis. Jan; 31(1):1-18.

Khuong Thuong, Vo Van Tuan,Wenfeng Li, Patrick Sorgeloos, Peter Bossier and Hans Nauwynck. (2017). Per os infectivity of white spot syndrome virus (WSSV) in white-legged shrimp (Litopenaeus vannamei) and role of 
peritrophic membrane. Veterinary Research201647:39.

Li, W., Xie, X.B., Shi, Q.S., Zeng, H.Y., Yng, Y.O.U., Chen, Y.B., (2010). Antibacterial activity and mechanism of silver nanoparticles on Escherichia coli. Appl. Microb. Biotechnol. 85, 11151122.

Mayer, A.M. and Hamann, M.T. (2005). Marine pharmacology in marine compounds with antidiabetic, antifungal, anti-inflammatory, and antiviral activities; affecting immune and nervous systems and other miscellaneous mechanisms of action. Comp Biochem Phycol C 140:265-286.

Salama A.A., Diab A.S., Abd El-Samie A.H. and Ahmed M .Abdel-Wahab (2009). Improving Isolation of White Spot Syndrome Virus on Mammalian Cell Lines. Zag. Vet. J.(ISSN. 1110-1458) Vol.37, No. 1 pp.10-16.

Salama A.A., Diab A.S., Abd El-Samie A.H. and Abdel-Wahab, A. M. (2008). Isolation and Identification of White
Spot Syndrome Virus from Egyptian Marine Shrimp. Zag. Vet. J.(ISSN. 1110-1458) Vol.36, No. 4 pp.105-113.

Shimizu, C., Shike, H., Klimpel, K.R., Burns, J.C., (2001). Hemolymph analysis and evaluationof newly formulated media for culture of shrimp cell (Penaeus stylirostris). In Vitro Cellular and Developmental Biology - Animal 37, 322-32.

Swaminathan R., V.S. Basheer, Chaudhary, N. and Raj. Kumar. (1992). Trypsin inhibitory activated in Basidiomcetae. Zentralblatt fur Mikrobiologie 147, $400-404$

Taylor,

R.S.L., Muli,F.W.,Njagi,E.N.M.,Njue,W. andKumon,K. (1996). AntiviralactivityoftheextractsofaKenyanmed icinalplantCarissaedulisagainstherpessi mplexvirus.J.Ethno-pharmacol.104,9299.

Wanger, E.F and Hewllet, M.J. (1999). Basic virology 2nd edition Malden scince. 